\title{
Lipid extraction methods from microalgae: a comprehensive review
}

\author{
Ramanathan Ranjith Kumar ${ }^{1}$, Polur Hanumantha Rao ${ }^{2}$ and Muthu Arumugam ${ }^{3 *}$ \\ ${ }^{1}$ Department of Plant Biology and Plant Biotechnology, Shree Chandraprabhu Jain College, Chennai, India \\ ${ }^{2}$ Department of Microbiology, Madras Christian College, Chennai, India \\ ${ }^{3}$ Division of Biotechnology, CSIR - National Institute for Interdisciplinary Science and Technology (NIIST), Trivandrum, India
}

\section{Edited by:}

Junye Wang, Athabasca University,

Canada

Reviewed by:

Reeta Rani Singhania, Blaise Pascal University, France

Lijuan Long, Chinese Academy of Sciences, China

*Correspondence:

Muthu Arumugam, Division of Biotechnology, CSIR - National Institute for Interdisciplinary Science and Technology (NIIST), Industrial

Estate (PO), Trivandrum 695019,

Kerala, India

e-mail:arumugam@niist.res.in, aasaimugam@gmail.com
Energy security has become a serious global issue and a lot of research is being carried out to look for economically viable and environment-friendly alternatives. The only solution that appears to meet futuristic needs is the use of renewable energy. Although various forms of renewable energy are being currently used, the prospects of producing carbonneutral biofuels from microalgae appear bright because of their unique features such as suitability of growing in open ponds required for production of a commodity product, high $\mathrm{CO}_{2}$-sequestering capability, and ability to grow in wastewater/seawater/brackish water and high-lipid productivity. The major process constraint in microalgal biofuel technology is the cost-effective and efficient extraction of lipids. The objective of this article is to provide a comprehensive review on various methods of lipid extraction from microalgae available, to date, as well as to discuss their advantages and disadvantages. The article covers all areas of lipid extraction procedures including solvent extraction procedures, mechanical approaches, and solvent-free procedures apart from some of the latest extraction technologies. Further research is required in this area for successful implementation of this technology at the production scale.

Keywords: microalgae, biomass energy, lipid extraction methods, algae biofuels, biodiesel, energy efficiency

\section{INTRODUCTION}

Environmental concerns and alarming energy crises are the major issues of the twenty-first century. To tackle with environmental concerns, creation of a pollution-free green environment is the need of the hour. At the same time, energy is inevitable in today's global scenario as almost all activities are driven by energy. Many sources and methods of energy generation have been/are being explored, and to date, it can be obtained from thermal, tidal, hydro, solar, mechanical, and nuclear power, or from fossil fuels. In fact, $85 \%$ of the energy, which we use, is obtained from fossil fuels, i.e., in the form of oil, coal, and natural gas, whereas renewable energy sources and nuclear power contributed only 13.5 and $6.5 \%$, respectively, to the total energy needs in 2007 (Asif and Muneer, 2007; Khan et al., 2009; Arumugam et al., 2011a). This situation has led us to solely depend on fossil fuels to sustain the energy requirements. However, an alarming concern is that the natural source of fossil fuel is finite and it is depleting very rapidly due to uncontrolled consumption, indicating the non-renewable nature of fossil fuels as energy sources.

Energy security has become a nationwide as well as a global issue, and a serious attempt is needed to search for viable alternatives in the form of renewable energy sources to meet the futuristic demand. Although prices are escalating, fossil fuels are a major source for use in transport and other sectors, and aside from this, they emit large amounts of carbon and hence have become a major cause of global warming. Against this backdrop, there is the pressing need to search for non-edible and eco-friendly alternative sources that paved the path for the emergence of the so-called "second- and third-generation biofuels." Secondgeneration biofuels are derived from any renewable feedstock other than edible feedstock sources, and the third-generation biofuels particularly emphasize the use of microorganisms. In this regard, microalgae seem to emerge as a potential viable alternative biofuel source because of their unique features, i.e., shorter generation time, suitability of growing in culture vessels and open ponds, high $\mathrm{CO}_{2}$-sequestering capability, ability to grow in wastewater/seawater/brackishwater, non-interference of food chain, and high-lipid productivity (Dunahay et al., 1992; Roessler et al., 1994; Sawayama et al., 1995; Sheehan et al., 1998; Banerjee et al., 2002; Gavrilescu and Chisti, 2005; Chisti, 2008; Arumugam et al., 2013). It is predicted that the algal biomass is a future attractive source for biofuel production mainly due to its potential to produce up to 10 times more oil per acre than traditional biofuel crops (Cooney et al., 2009). However, algae-based biofuel can be commercialized on a larger scale with the development of a suitable cost-effective growth medium (Arumugam et al., 2011b), low-energy-intensive harvesting method, and effective lipid extraction method. Among the difficulties involved in commercial deployment of microalgal biofuel technology, costeffective and efficient extraction of lipids remains a major bottleneck. Even in a recent concept of fourth-generation biofuels, which proposes the use of recombinant organisms to produce high amount of lipids, the above problem has to be addressed. This article focuses on the above major limitation of algal biofuel R\&D in detail with available methods to extract lipids from microalgae. 
Unlike for terrestrial oilseed crops, the oil expeller/press cannot be employed for extracting lipids from microalgae, the reasons being small cell size, complex cell membrane, and thick and rigid cell wall (Ruan et al., 2006; Cho et al., 2012). Therefore, oil extraction from algae is performed by adopting non-traditional, costly techniques such as using organic solvents, electroporation, ultrasonic, and supercritical $\mathrm{CO}_{2}$ methods. The objective of this article is to provide a timely review on comprehensive methodological/analytical insights into the field of microalgal oil extraction and their benefits and constraints.

\section{ALGAE BIOMASS/LIPID AS A SOURCE OF BIOENERGY}

Microalgae are a promising feedstock for the production of biofuels. Various biofuels can be produced based on the chemical composition of the algal biomass feedstock. They include biodiesel, bioethanol, biobutanol, biomethane, jet fuel, biohydrogen, and thermochemical conversion products such as bio-oil, biocrude, and syngas (Chinnasamy et al., 2012). A lot of research is being carried out for developing microalgal biodiesel technology by performing bioprospecting of high-lipid-containing strains as well as by inducing higher lipid production by various physiological and genetic strain improvement methods. Therefore, lipid extraction is an extremely important process for the production of microalgal biodiesel. There are also other methods such as algal biorefinery for the production of multiple algal products and thermochemical technology for the production of biocrude. As fuels are a commodity product, extraction of lipids from algae is technically and economically viable even in integrated concepts. When produced in huge quantities, extraction of lipid for biodiesel production from strains containing even around 10\% lipid content will be feasible.

\section{TOTAL LIPID EXTRACTION METHODS FOLCH METHOD}

Various organic solvents or combination of different solvents have been suggested to selectively extract lipids from a complex mixture of organic compound. The Folch method (Folch et al., 1957) employs the use of chloroform-methanol (2:1 by volume) for extraction of lipids from endogenous cells. Briefly, the homogenized cells were equilibrated with one-fourth volume of saline solution and mixed well. The resulting mixture was allowed to separate into two layers and lipids settle in the upper phase. This method is one of the oldest initiatives in lipid extraction, which formed the basis for development of future extraction procedures with improvements. The above method with some modification is still used for the estimation of algal lipids spectrophotometrically. Rapid and easy processing of large number of samples is the major advantage of this method. However, it is less sensitive when compared with other latest procedures.

\section{BLIGH AND DYER METHOD}

Lipid extraction and partitioning are performed simultaneously in the Bligh and Dyer (1959) method, wherein proteins are precipitated in the interface of two liquid phases. The Bligh and Dyer method is one of the widely practised methods for lipid extraction. It is very similar to the Folch method, but mainly differs in solvent/solvent and solvent/tissue ratios. This procedure is performed by extracting lipids from homogenized cell suspension using 1:2 (v/v) chloroform/methanol. The lipids from the chloroform phase are then extracted and processed by various procedures, which are not described here. The above gravimetric method is still widely used for the estimation of lipids by algal technologists, and the same procedure is also followed for pilot-scale and large-scale extraction processes.

In order to improve the above basic method, many modifications have been adopted by researchers. The most common modification is the addition of $1 \mathrm{M} \mathrm{NaCl}$ instead of water, to prevent binding of acidic lipids to denatured lipids. It was also reported that addition of $0.2 \mathrm{M}$ phosphoric acid (Hajra, 1974) and $\mathrm{HCl}$ (Jensen et al., 2008) to the salt solution improves lipid recovery with a shorter separation time in comparison with the earlier extraction methods. Similarly, addition of $0.5 \%(\mathrm{v} / \mathrm{v})$ acetic acid to the water phase increased the recovery of acidic phospholipids (Weerheim et al., 2002). A more recent report suggests that Hajra's method of lipid extraction was demonstrated to be the most efficient procedure for the extraction of plant sphingolipids (Markham et al., 2006).

\section{EXTRACTION OF ALL CLASSES OF LIPIDS}

The most recent and rigorous method was suggested by Matyash et al. (2008), which is a modification of the Folch/Bligh and Dyer method. The above method provides better recovery of almost all major classes of lipids. Methyl-tert-butyl ether (MTBE) was used as a solvent for the extraction of lipids, and this method provides the most accurate lipidome profile. This is possibly achieved because of the formation of a low-density, lipid-containing organic upper phase, which is easy to extract completely. In brief, for a $200 \mathrm{ml}$ sample, $1.5 \mathrm{ml}$ of methanol was added and mixed rigorously (vortexing) followed by the addition of $5 \mathrm{ml}$ of MTBE and the mixture was incubated for $1 \mathrm{~h}$ at room temperature. A volume of $1.25 \mathrm{ml}$ of water was added to the mixture and allowed to stand at room temperature for $10 \mathrm{~min}$ to develop phase separation. The upper organic phase was collected after centrifugation at $1000 \times g$ for $10 \mathrm{~min}$. It is advisable to re-extract the lower phase with fresh addition of $2 \mathrm{ml}$ of MTBE/methanol/water (10/3/2.5, $\mathrm{v} / \mathrm{v} / \mathrm{v}$ ) to achieve complete lipid recovery. Both the organic phases containing the lipid extract can be vacuum dried to drain off the excess solvent. The extracted lipids were dissolved in $200 \mathrm{ml}$ of chloroform/methanol/water $(60 / 30 / 4.5, \mathrm{v} / \mathrm{v} / \mathrm{v})$ for storage or can be directly used for further analysis (Matyash et al., 2008). All the above-mentioned methods are applicable for lipid extraction from all types of lipid-bearing cells, including microalgae.

\section{SUPERIOR SOLVENT EXTRACTION METHODS}

The above solvent methods usually use chloroform as the extracting solvent; even though the extraction is very effective, large-scale lipid extraction using these methods is precluded by environmental and health risks. Therefore, less-toxic, but less effective, substitutes such as ethanol, isopropanol, butanol, MTBE, acetic acid esters, hexane, and various combinations of solvents have been investigated by many researchers for microalgal lipid extraction (Sheng et al., 2011). Again, the use of the above solvents depends on the class of lipids to be extracted. However, in a recent research report, use of 2-ethoxyethanol (2-EE) was shown to provide 
superior lipid recovery compared to other common extraction solvents such as chloroform:methanol and hexane (Jones et al., 2012). Accelerated solvent extraction (ASE) process, using heat or pressure, has also been used to achieve better lipid recovery, shorten process time, and recover solvent for re-use (Cooney et al., 2009). Many improved solvent extraction methods as well as combined solvent/physical extraction systems are being researched across the globe; however, extraction systems involving organic solvents have their own disadvantages when implemented on a larger scale.

\section{IN SITU LIPID HYDROLYSIS AND SUPERCRITICAL IN SITU TRANSESTERIFICATION}

Very recently, an in situ lipid hydrolysis and supercritical in situ transesterification (SC-IST/E) method for lipid extraction from wet algal biomass was reported by Levine et al. (2010). In this method, wet algal biomass is processed for the extraction of lipids followed by transesterification to obtain biodiesel, and therefore, it gains significance in the field of algal biofuel R\&D. In brief, wet algal biomass was kept in a stainless steel reactor immersed in a pre-heated isothermal fluidized sand bath for the desired time and then promptly removed and cooled in water. Hydrolysis reaction was carried out simultaneously at each condition in two other reactors. Then, the dried algal biomass $(1 \mathrm{~g})$ was mixed with $4 \mathrm{~g}$ of water in a large reactor $(10 \mathrm{ml})$, and the reaction was continued for $15,30,45$, and $60 \mathrm{~min}$ at $250^{\circ} \mathrm{C}$. In this method, simultaneous drying and dehydration converts the wet algal biomass into a solid, and this process facilitates precise loading of solids in hydrolysis reactions. Upon cooling, the aqueous phase and solids were separated under light vacuum condition using an appropriate filter (934-AH filter paper; Whatman). A detailed experiment was then carried out to determine the effects of reaction temperature, reaction time, and ethanol loading on the yield and composition of crude biodiesel. The resulting crude algal oil was tested for its quality standards using appropriate methods (Levine et al., 2010). However, the above method has to be tested for its commercial feasibility in a large-scale cultivation facility.

\section{ALGAL OIL EXTRACTION - A MECHANICAL APPROACH}

Apart from the above methods, many mechanical methods are being used to extract lipids from microalgae both at pilot-scale and commercial levels. Mechanical methods present an effective approach because of less dependence on the type of microalgae species to be processed and they are also less likely to cause contamination of the extracted lipid product. However, the above methods usually require higher energy inputs than the chemical or enzymatic methods. Moreover, heat generation during mechanical disruptions can cause damage to the end products and a cooling system becomes vital during extraction of heatsensitive products. The energy and equipment costs for installation and functioning of a cooling system will add up to the process costs (Lee et al., 2012). Some of the mechanical extraction processes that do not necessarily require solvent assistance, include bead mills (Richmond, 2004), expeller press procedure (Ramesh, 2013), microwave-assisted pyrolysis extraction (Du et al., 2011) as well as ultrasound-assisted extractions, pulsed electric field, and hydrothermal liquefaction (Brown et al., 2010).

\section{EXPELLER PRESS}

Expeller press or oil press is one of the simplest and oldest methods used for extracting oil from oil seeds. The simple, yet effective, mechanical crushing method is also being used in the extraction of oil from algal biomass (Demirbas, 2009). Dried algal biomass retains oil content, which then can be pressed out using an oil press. The principle underlying this technique is to apply highmechanical pressure for crushing and breaking the cells, and to squeeze out the oil from the algal biomass. Application of pressure in a particular range improves the extraction efficiency, but too much of pressure will result in decreased lipid recovery, increased heat generation, and choking problems (Ramesh, 2013). Algal biomass characteristics vary widely, particularly in their physical attributes, based on the morphological differences of different strains, and various tailor-made press configurations (screw, expeller, piston, etc.) are required. Usually, the oil recovery is in the range of $70-75 \%$. Sometimes for enhanced oil recovery, mechanical crushing is used in conjunction with chemical methods. However, press methods are expensive and involve prolonged processing times (Boldor et al., 2010). In addition, mechanical pressing generally requires input materials with very low-moisture content, and drying of the algae biomass, which is an energyintensive process, can account for up to $30 \%$ of the total production costs. Unlike vegetable oils, which can be easily extracted by crushing the seeds accompanied by a solvent extraction, releasing oil from algal cells is hindered by the rigid cell wall structure (Johnson and Wen, 2009). The major technical drawback is the presence of pigments along with oil. Before conversion to oil, the pigments have to be removed either by solvent extraction or by activated carbon adsorption, which again adds up to the cost. Other major drawbacks of this method include high-maintenance cost, requirement of skilled labor, and less efficiency compared to other methods (Ramesh, 2013).

\section{BEAD BEATING}

Bead beating is a mechanical method for the disruption of cells, where a direct damage to the cells is caused by the concept of high-speed spinning of the biomass slurry with fine beads (Lee et al., 1998; Geciova et al., 2002). In bead mills, the cells are disrupted by the impact of grinding beads against the cells. All types of cells including those of microalgae can be processed by the above method. Shaking vessels and agitated beads are the two common types of bead mills. In the shaking vessel type, the cells are damaged by shaking the entire culture vessel. Usually, multiple vessels are shaken on a vibrating platform and this type of bead mill is suited for samples requiring similar disruption treatment conditions. Hence, this set-up can be exclusively used on a laboratory scale. Better disruption and extraction efficiencies can be obtained with the second type, where the beads are agitated along with the cell culture. As the rotating agitator inside the culture vessel generates heat, the vessels are provided with cooling jackets to protect the heat-sensitive biomolecules. Unquestionably, the combined effect of agitation, collision, and grinding of the beads produces a more effective disruption process (Lee et al., 2012). Similarly, dewatering of algal slurry is not required unlike in the expeller press method and this contributes to reduction in processing costs. Various beads are used for different types of cells; 
the optimal bead diameter for microalgae cells is $0.5 \mathrm{~mm}$ and the optimal volume fraction of bead loading is about $0.5 \mathrm{~mm}$. Beads made of zirconia-silica, zirconium oxide, or titanium carbide can enhance the disruption rates and extraction efficiency of microalgal cells, presumably because of their greater hardness and density (Hopkins, 1991).

\section{ULTRASONIC-ASSISTED EXTRACTION}

Ultrasound-assisted extraction of lipids is an alternative technique, which is devoid of the difficulties associated with the conventional mechanical disruption methods. The process is simple with easy working set-up conditions, imparting higher purity to the final product and eliminating treatment of wastewater generated during the process. Furthermore, the technique is more economical and eco-friendly and can be completed in a very short time with high reproducibility. The energy input is very little when compared to that in conventional methods, and can be operated at lower temperatures (Chemat et al., 2011). When liquid cultures are used, there are two major mechanisms by which ultrasound can cause damage to the cells, namely, cavitation and acoustic streaming. Cavitation is the production of microbubbles as a result of the applied ultrasound, which in turn can create pressure on the cells to break up (Suslick and Flannigan, 2008), and acoustic streaming facilitates mixing of the algal culture (Khanal et al., 2007). The ultrasonic waves generate transient and stable cavitation due to the rapid compression/decompression cycles occurring during the treatment. Unsteady oscillations will result in transient cavitation, which will ultimately implode. A cavitation implosion produces extremely localized heat shock waves, which disrupt the microalgal cells (Brujan et al., 2001). Thus, sonication cracks the cell wall and membrane due to the cavitation effect (Engler, 1985; Harrison, 1991; Hosikian et al., 2010; Adam et al., 2012). Microstreaming and heightened mass transfer resulting from cavitation and bubble collapse are the two critical steps to determine the lipid yield extraction efficiency (Adam et al., 2012).

Horn and bath are the two basic types of sonicators and both processors are commonly employed in batch operations but can be adapted for continuous operations as well (Hosikian et al., 2010). Piezoelectric generators made of lead zirconate titanate crystals are used in horns, which vibrate with an amplitude of $10-15 \mathrm{~mm}$, whereas sonicator baths use transducers, which are placed at the bottom of the reactor to generate ultrasonic waves. In the bath type, the capacity and shape of the reactor determine the number and arrangement of transducers (Lee et al., 2012). The major advantage of the sonication process is that it generates relatively low temperatures when compared to microwave reactors and autoclaves, thereby leading to less thermal denaturation of biomolecules.

Furthermore, it does not require the addition of beads or chemicals, which have to be removed later in the process, which in turn will incur more cost (Harrison, 1991). However, prolonged ultrasonication leads to the production of free radicals, which may be detrimental to the quality of the oil that is being extracted (Mason et al., 1994).

\section{MICROWAVE}

Earlier, the applications of microwave radiation were limited to the digestion of samples for measuring trace metals
(Huffer et al., 1998) and extraction of organic contaminants (Marcato and Vianello, 2000). The feasibility of extracting lipids using microwave irradiation was first reported in the mid-1980s (Ganzler et al., 1986). They developed a microwave extraction technique for isolating lipids and pesticides from seeds, foods, feeds, and soil, which was more effective than the conventional procedures. Thus, microwave technology has allowed the development of rapid, safe, and economical methods for extracting lipids and does not require dewatering of algal biomass (Pare et al., 1997). Similarly, use of microwave remains the most simple and most effective method among the other tested methods for microalgal lipid extraction (Lee et al., 2010). A dielectric or polar material introduced in a rapidly oscillating electric field, such as that produced by microwaves, will generate heat because of the frictional forces arising from inter- and intra-molecular movements (Amarni and Kadi, 2010). Intracellular heating results in the formation of water vapor, which disrupts the cells from within. This in turn leads to the electroporation effect, which further opens up the cell membrane, thereby rendering efficient extraction of intracellular metabolites (Rosenberg and Bogl, 1987). Thus, rapid generation of heat and pressure within the biological system forces out compounds from the cell matrix, resulting in the production of good-quality extracts with better target compound recovery (Hemwimon et al., 2007). Sostaric et al. (2012) suggested that microwave-pretreated microalgae have higher bio-oil yields because of the presence of several micro-cracks in the cell wall. Microwaves can also be used to extract and transesterify the oils into biodiesel. Microwaves are the pick of the options at present because of the economics involved in the above process; it is expected to be attractive due to short reaction time, low-operating costs, and efficient extraction of algal oils. It was also reported that the recovery of biodiesel from the reaction mixture in a microwave-assisted process is approximately 15-20 min, which is far quicker when compared to the 6-h period in the conventional heating method (Refaat et al., 2008). However, the disadvantage with the microwave-assisted process is the maintenance cost involved, particularly on a commercial scale.

\section{ALGAL OIL EXTRACTION USING ELECTROPORATION}

Electroporation, or electropermeabilization, is a membrane phenomenon, which involves a significant increase in the electrical conductivity and permeability of the algal cell wall and cytoplasmic membrane resulting from an externally applied electrical field. According to Sommerfeld et al. (2008), electroporation/electropermeabilization altered the cellular membranes and cell walls of tested algal cells and improved lipid extraction efficiency in terms of time and solvent use without affecting the composition and quality of extracted fatty acids. They also report that $92 \%$ of the total lipid was extracted from the algal biomass after a single electroporation treatment, while only $62 \%$ of the total lipid was extracted from the same amount of algal biomass without the electroporation treatment.

\section{A NOVEL INITIATIVE BY AN INDUSTRY TO EXTRACT ALGAL LIPIDS}

As commercialization of third-generation biofuels is still in its nascent stages, several initiatives and methodologies are being developed by industries, research and academic institutes across the world. One such attempt, which is worthy of mention here, is 


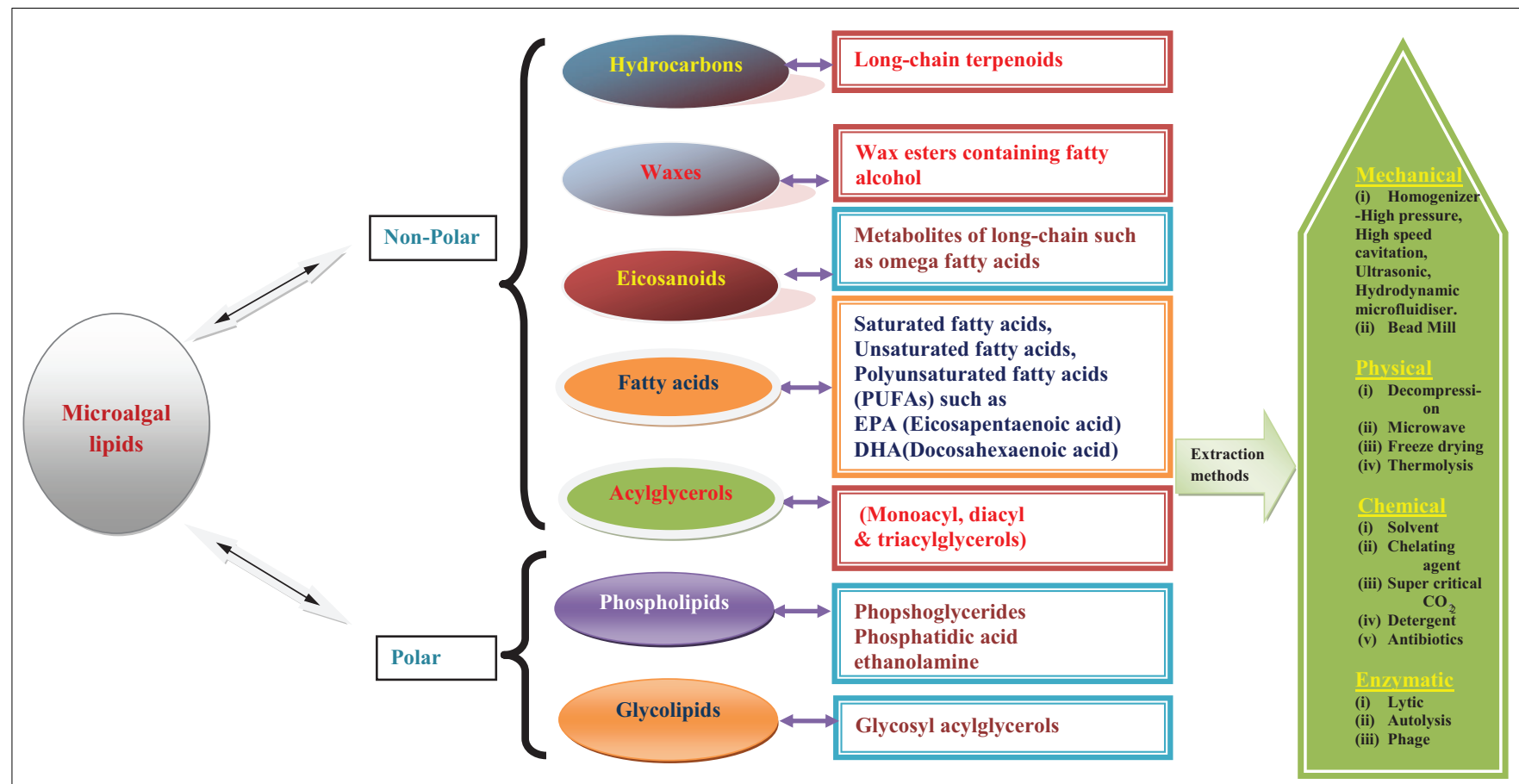

FIGURE 1 | Different classes of microalgal lipids with example and common extraction methods.

an industry initiative by OriginOil, which has developed a technology that does not use organic solvents for algal oil extraction. Instead, it uses low-wattage, frequency-tuned microwave bursts that break the rigid and complex algal cell walls. Quantum fracturing is then applied to the now pre-cracked cells to complete the oil extraction with ease. This unique approach makes lowenergy and environmentally safe algae oil production a reality as reported by the OriginOil company. Overall description of different classes of algal lipids and their extraction procedure is schematically represented (Figure 1).

\section{SOLVENT-FREE EXTRACTION METHODS FOR ALGAL BIOMASS}

As discussed earlier, in general, lipid extraction from algal biomass is typically carried out using organic solvents such as hexane, chloroform, petroleum ether, acetone, and methanol. At present, no other potential alternatives are available, which can overcome the fire hazards and huge costs involved in the utilization of organic solvents. Although organic solvent-based extraction works fairly well with some algal strains, it is not widely applicable for all algal strains and it also consumes time and labor. Similarly, mechanical approaches may prove costly and cause damage to the end products.

All the methods discussed above have their advantages and disadvantages, but none of them has been confirmed as a suitable extraction method for algal fuel production (Ranjan et al., 2010; Rawat et al., 2013). An innovative efficient ecoextraction/fractionation process technique apart from mechan$\mathrm{ical} / \mathrm{solvent}$ extraction approaches could result in the reduction or control of the production costs. Adam et al. (2012) reported
Table 1 | Selective advantages of solvent-free lipid extraction methods.

\begin{tabular}{|c|c|c|}
\hline Process & Technologies & Advantages of solvent-free extraction \\
\hline \multirow[t]{6}{*}{$\begin{array}{l}\text { Lipid } \\
\text { extraction }\end{array}$} & $\begin{array}{l}\text { Solvent-free } \\
\text { extraction }\end{array}$ & $\begin{array}{l}\text { Most simple, easy, and preferred dedicated } \\
\text { method }\end{array}$ \\
\hline & & $\begin{array}{l}\text { Increase lipid extraction efficiency at } \\
\text { optimum level and non-toxic process }\end{array}$ \\
\hline & & $\begin{array}{l}\text { Solvent-free extraction method can be used } \\
\text { for both wet and dry algal biomass }\end{array}$ \\
\hline & & To avoid risk of medium contamination \\
\hline & & $\begin{array}{l}\text { Reduce extraction time much less than other } \\
\text { methods }\end{array}$ \\
\hline & & It gives high purity of the final product \\
\hline
\end{tabular}

that solvent-free extraction is often an ecologic and more economic process; indeed, it needs no supplementary energy to separate phases and elimination of the solvent is not necessary if no final product recirculation system exists. Very few studies have been dedicated for developing non-solvent extraction and non-mechanical methods such as use of osmotic pressure and isotonic solution. These methods may prove to be economically and technically sustainable, eco-friendly, and easily scalable (Table $\mathbf{1}$ ).

\section{OSMOTIC PRESSURE METHOD}

An innovative and alternate approach of using osmotic pressure is considered an ecological and cost-effective way to compete with other extraction methods (Adam et al., 2012). Osmotic pressure can disturb algal cell walls through a hasty increase and decrease 
Table 2 | Comparison of different lipid extraction methods: cost and energy efficiency.

\begin{tabular}{|c|c|c|c|c|c|c|}
\hline SI. No & Method & $\begin{array}{l}\text { Lipid extraction } \\
\text { efficiency }\end{array}$ & $\begin{array}{l}\text { Efficiency } \\
\text { rating }^{a}\end{array}$ & Cost involved & Energy requirement & Remarks \\
\hline 1 & $\begin{array}{l}\text { Use of organic } \\
\text { solvents such as } \\
\text { chloro- } \\
\text { form/methanol, } \\
\text { hexane, and ether }\end{array}$ & $\begin{array}{l}\text { Extraction efficiency } \\
\text { depends on the species } \\
\text { used, volume of the } \\
\text { extractor, reaction time, } \\
\text { sample volume, } \\
\text { moisture content, types } \\
\text { of lipids present, and in } \\
\text { case of solvent-based } \\
\text { methods, choice of the } \\
\text { solvents, solvent ratios, } \\
\text { etc }\end{array}$ & Moderate & $\begin{array}{l}\text { High due to the use of } \\
\text { solvents. Re-use may } \\
\text { help save some costs } \\
\text { but again an } \\
\text { energy-intensive } \\
\text { process }\end{array}$ & Energy intensive & $\begin{array}{l}\text { Fire, health, and } \\
\text { environmental hazards; } \\
\text { regulatory issues }\end{array}$ \\
\hline 3 & $\begin{array}{l}\text { Isotonic } \\
\text { extraction }\end{array}$ & & Moderate-high & $\begin{array}{l}\text { High cost of the } \\
\text { solvents as the solvents } \\
\text { used are synthetic } \\
\text { "green" non-volatile } \\
\text { solvents }\end{array}$ & Energy intensive & Less hazardous \\
\hline 4 & Supercritical $\mathrm{CO}_{2}$ & & High & High cost & $\begin{array}{l}\text { Energy-intensive due to } \\
\text { use of high pressure }\end{array}$ & $\begin{array}{l}\text { Environmental and } \\
\text { safety issues }\end{array}$ \\
\hline 7 & Microwave & & Very high & $\begin{array}{l}\text { Initial investment and } \\
\text { maintenance costs high }\end{array}$ & $\begin{array}{l}\text { Energy demand is too } \\
\text { high (also requires } \\
\text { energy for cooling) }\end{array}$ & $\begin{array}{l}\text { Easy to scale up, but } \\
\text { yet to be standardized } \\
\text { at a commercial level }\end{array}$ \\
\hline 8 & $\begin{array}{l}\text { Sonication } \\
\text { method }\end{array}$ & & High & $\begin{array}{l}\text { Initial investment and } \\
\text { maintenance costs high }\end{array}$ & $\begin{array}{l}\text { Energy intensive } \\
\text { (requires energy for } \\
\text { both sonication and } \\
\text { cooling) }\end{array}$ & $\begin{array}{l}\text { Poor product quality } \\
\text { due to the damage } \\
\text { during the process }\end{array}$ \\
\hline 9 & $\begin{array}{l}\text { Osmotic shock } \\
\text { method }\end{array}$ & & Moderate-high & Low-cost method & Less energy & $\begin{array}{l}\text { Requires longer } \\
\text { treatment time (not } \\
<48 \mathrm{~h} \text { ) }\end{array}$ \\
\hline 10 & Electroporation & & Very high & $\begin{array}{l}\text { Initial investment and } \\
\text { maintenance costs } \\
\text { high, but operates at } \\
\text { comparatively lower } \\
\text { costs }\end{array}$ & Less energy & $\begin{array}{l}\text { Appears promising but } \\
\text { detailed pilot-scale } \\
\text { studies have to be } \\
\text { carried out }\end{array}$ \\
\hline
\end{tabular}

\footnotetext{
${ }^{a}$ Rating is tentative and can be improvised by technology development.
} 
in the salt concentration of the aqueous media; this can disturb the balance of osmotic pressure between the interior and exterior of the algal cells. Algal cell damage can occur by two osmotic stresses - hyper-osmotic and hypo-osmotic. When the salt concentration is higher in the exterior, the cells suffer hyper-osmotic stress. As a result, the cells shrink as fluids inside the cells diffuse outwards, and damage is caused to the cell envelopes. In contrast, hypo-osmotic stress occurs when the salt concentration is lower in the exterior; the fluid flows into the cells to balance the osmotic pressure, and the cells swell or burst if the stress is too high. Hypo-osmotic shock is a procedure commonly used for the extraction of intracellular substances from microorganisms. According to some authors, positive results could be achieved by using the osmotic pressure method for the extraction of oil from various microalgal biomasses such as those of Chlamydomonas reinhardtii (Lee et al., 2010), Botryococcus sp., Chlorella vulgaris, and Scenedesmus sp. (Yoo et al., 2012). Thus, it was concluded that the osmotic pressure method would appear to be the most simple, easy, and efficient method for lipid extraction from microalgae (Yoo et al., 2012; Kim and Yoo, 2013). Further research is warranted on lipid extraction using the osmotic pressure method from different algal species including marine strains. Similarly, feasibility of using this technology at the pilot- and production-scale levels has to be tested.

\section{ISOTONIC EXTRACTION METHOD}

Use of ionic liquid for algal lipid extraction is an innovative and emerging alternative pre-treatment technology. Intensive studies on ionic liquid extraction in microbes have been carried out by various researchers and it is more bio-attuned regardless of detailed procedures (Li et al., 2010; Klein-Marcuschamer and Simmons, 2011; Wang et al., 2011; Ninomiya et al., 2012; Huang and Wang, 2013). The idea is to replace toxic organic solvents with ionic liquids, the so-called "green" designer solvent. Ionic liquids are non-aqueous solution of salts that could be maintained at liquid state at moderate temperatures ranging between 0 and $140^{\circ} \mathrm{C}$. They are composed of a large asymmetric organic cation and an inorganic or organic anion. These ionic liquids allow synthetic flexibility by the distinct combination of the anion and cation so that one can design the solvent's specific polarity, hydrophobicity, conductivity, and solubility according to needs (Cooney et al., 2009). However, only few studies have been performed on microalgal species such as Chlorella vulgaris (Kim and Choi, 2012) to extract lipid through eco-friendly ionic liquid extraction method. The economic and technical viability has not been worked out so far and it is too early to predict that this method is one of the better methods for algal oil extraction. However, this method appears to be promising, as it can be an eco-friendly alternative for organic solvents. A brief review of the above methods is given in Table 2 .

\section{ENZYME-ASSISTED EXTRACTION}

A novel method of extracting microalgal lipids includes the use of enzymes to facilitate cell disruption. Addition of enzymes such as cellulase and trypsin to the microalgal biomass will enable the intracellular lipids to be extracted easily after degradation of tough polymers present on the cell surface structures (Taher et al., 2014). The above method is highly specific and rapid, but it is affected by the lipid class composition and type of microalgae (Liang et al., 2012). Moreover, this method requires operation at low temperatures with high specificity/selectivity for better efficiency (Taher et al., 2014). Although cost intensive, this method is advantageous because excess energy is required to break the rigid cell wall by mechanical methods.

\section{CONCLUDING REMARKS}

Successful commercialization of this technology relies on optimization of microalgal growth, effective lipid extraction, and conversion of the same to biodiesel. However, efficient lipid extraction and highest recovery remain the vital downstream processing difficulties in the algal biofuel industry. At present, solvent extraction methods are most commonly used for lipid extraction as they provide the highest lipid recovery. Use of mechanical methods, though environment friendly and cheap, is not a wise option because of poor recovery and the possible degradation of lipids. Solvent-free methods appear promising at the laboratory scale at present and more research has to be carried out for minimal use of solvents for large-scale commercialization. A more promising way for effective and efficient lipid extraction could be to use combinative methods such as enzymatic and mechanical/solvent extraction methods. Solvent-free methods such as enzymatic degradation when combined with other methods will reduce solvent usage/energy consumption and also increase recovery efficiency. For successful commercialization and cost-effective production of microalgae biofuels, the above problem has to be addressed comprehensively and this goal can be achieved through constant R\&D efforts by the academia, research institutions, and industries.

\section{ACKNOWLEDGMENTS}

The authors acknowledge Mr. Anand, DST project fellow, Biotechnology Division, CSIR-NIIST, Trivandrum, for his help in preparing this manuscript. We also thank Mr. T. Balaji Prasad, Scientific Publishing Services Pvt. Ltd., Chennai, for his timely help in improving the language of the manuscript.

\section{REFERENCES}

Adam, F., Abert-Vian, M., Peltier, G., and Chemat, F. (2012). "Solvent-free" ultrasound-assisted extraction of lipids from fresh microalgae cells: a green, clean and scalable process. Bioresour. Technol. 114, 457-465. doi:10.1016/j.biortech. 2012.02.096

Amarni, F., and Kadi, H. (2010). Kinetics study of microwave-assisted solvent extraction of oil from olive cake using hexane: comparison with the conventional extraction. Innov. Food Sci. Emerg. Technol. 11, 322-327. doi:10.1016/j.ifset.2010. 01.002

Arumugam, M., Agarwal, A., Arya, M. C., and Ahmed, Z. (2011a). Microalgae: a renewable source for second generation biofuel. Curr. Sci. 100, 1141-1142. doi:10.1007/s00253-009-1935-6

Arumugam, M., Agarwal, A., Arya, M. C., and Ahmed, Z. (2011b). Influence of organic and inorganic nitrogen sources on biomass yield of Scenedesmus sp. and Chlorococcum sp. Int. J. Energy Environ. 2, 1125-1132. Available at: http://www.ijee.ieefoundation.org/vol2/issue6/IJEE_13_v2n6.pdf

Arumugam, M., Agarwal, A., Arya, M. C., and Ahmed, Z. (2013). Influence of nitrogen sources on biomass productivity of microalgae Scenedesmus bijugatus. Bioresour. Technol. 131, 246-249. doi:10.1016/j.biortech.2012.12.159

Asif, M., and Muneer, T. (2007). Energy supply, its demands and security issues for developed and emerging economies. Renew. Sustain. Energ. Rev. 11, 1388-1413. doi:10.1016/j.rser.2005.12.004

Banerjee, A., Sharma, R., Chisti, Y., and Banerjee, U. C. (2002). Botryococcus braunii: a renewable source of hydrocarbons and other chemicals. Crit. Rev. Biotechnol. 22, 245-279. doi:10.1080/07388550290789513 
Bligh, E. G., and Dyer, W. J. (1959). A rapid method of total lipid extraction and purification. Can. J. Biochem. Physiol. 37, 911-917. doi:10.1139/o59-099

Boldor, D., Kanitkar, A., Terigar, B. G., Leonardi, C., Lima, M., and Breitenbeck, G. A. (2010). Microwave assisted extraction of biodiesel feedstock from the seeds of invasive Chinese Tallow tree. Environ. Sci. Technol. 44, 4019-4025. doi:10.1021/es100143z

Brown, T. M., Duan, P., and Savage, P. E. (2010). Hydrothermal liquefaction and gasification of Nannochloropsis sp. Energy Fuels 24, 3639-3646. doi:10.1021/ ef100203u

Brujan, E. A., Nahen, K., Schmidt, P., and Vogel, A. (2001). Dynamics of laser induced cavitation bubbles near an elastic boundary. J. Fluid Mech. 433, 251-281. doi:10.1017/S0022112000003335

Chemat, F., Zill, E. H., and Khan, M. K. (2011). Applications of ultrasound in food technology: processing, preservation and extraction. Ultrason. Sonochem. 18, 813-835. doi:10.1016/j.ultsonch.2010.11.023

Chinnasamy, S., Rao, P. H., Bhaskar, S., Rengasamy, R., and Singh, M. (2012). "Algae: a novel biomass feedstock for biofuels," in Microbial Biotechnology: Energy and Environment, ed. R. Arora (Wallingford: CAB International), 224-239.

Chisti, Y. (2008). Biodiesel from microalgae beats bioethanol. Trends Biotechnol. 26, 126-131. doi:10.1016/j.tibtech.2007

Cho, S. C., Choi, W. Y., Oh, S. H., Lee, C. G., Seo, Y. C., Kim, J. S., et al. (2012). Enhancement of lipid extraction from marine microalga, Scenedesmus, associated with high-pressure homogenization process. J Biomed Biotechnol 2012, 359432. doi:10.1155/2012/359432

Cooney, M., Young, G., and Nagle, N. (2009). Extraction of bio-oils from microalgae. Sep. Purif. Rev. 38, 291-325. doi:10.1080/15422110903327919

Demirbas, A. (2009). Production of biodiesel from algae oils. Energ. Source 31, 163-168. doi:10.1080/15567030701521775

Du, Z., Li, Y., Wang, X., Wan, Y., Chen, Q., Wang, C., et al. (2011). Microwaveassisted pyrolysis of microalgae for biofuel production. Bioresour. Technol. 102, 4890-4896. doi:10.1016/j.biortech.2011.01.055

Dunahay, T. G., Jarvis, E. E., Dais, S. S., and Roessler, P. G. (1992). Genetic engineering of microalgae for fuel production. Appl. Biochem. Biotechnol. 34, 331-339. doi:10.1007/BF02920556

Engler, C. R. (1985). "Disruption of microbial cells," in Comprehensive Biotechnology, 2nd Edn, ed. M. Moo-Yoong (Oxford: Pergamon Press), 305-324.

Folch, J., Lees, M., and Sloane Stanley, G. H. (1957). A simple method for the isolation and purification of total lipids from animal tissues. J. Biol. Chem. 226, 497-509.

Ganzler, K., Salgo, A., and Valko, K. (1986). Microwave extraction. A novel sample preparation method for chromatography. J. Chromatogr. 37, 299-306. doi:10.1016/S0021-9673(01)94714-4

Gavrilescu, M., and Chisti, Y. (2005). Biotechnology - a sustainable alternative for chemical industry. Biotechnol. Adv. 23, 471-499. doi:10.1016/j.biotechadv.2005. 03.004

Geciova, J., Bury, D., and Jelen, P. (2002). Methods for disruption of microbial cells for potential use in the dairy industry - a review. Int. Dairy J. 12, 541-553. doi:10.1016/S0958-6946(02)00038-9

Hajra, A. K. (1974). On extraction of acyl and alkyl dihydroxyacetone phosphate from incubation mixtures. Lipids 9, 502-505. doi:10.1007/BF02532495

Harrison, S. T. L. (1991). Bacterial cell disruption: a key unit operation in the recovery of intracellular products. Biotechnol. Adv. 9, 217-240. doi:10.1016/07349750(91)90005-G

Hemwimon, S., Pavasant, P., and Shotipruk, A. (2007). Microwave-assisted extraction of antioxidative anthraquinones from roots of Morinda citrifolia. Sep. Purif. Technol. 54, 44-50. doi:10.1016/j.seppur.2006.08.014

Hopkins, T. R. (1991). "Physical and chemical cell disruption for the recovery of intracellular protein," in Purification and Analysis of Recombinant Proteins, eds R. Seetharam and S. Sharma (New York, NY: Marcel Dekker), 57-84.

Hosikian, A., Lim, S., Halim, R., and Danquah, M. K. (2010). Chlorophyll extraction from microalgae: a review on the process engineering aspects. Int. J Chem. Eng. 2010, 391632. doi:10.1155/2010/391632

Huang, Q., and Wang, Q. (2013). Effects of selected ionic liquids on lipid production by the oleaginous yeast Rhodosporidium toruloides. Bioresour. Technol. 130, 339-344. doi:10.1016/j.biortech.2012.12.022

Huffer, J. W., Westcott, J. E., Miller, L. V., and Krebs, N. F. (1998). Microwave method for preparing erythrocytes for measurement of zinc concentration and zinc stable isotope enrichment. Anal. Chem. 70, 2218-2220. doi:10.1021/ac971083d
Jensen, G. S., Wu, X., Patterson, K. M., Barnes, J., Carter, S. G., Scherwitz, L., et al. (2008). Improved Bligh and Dyer extraction procedure. Lipid Technol. 20, 280-281. doi:10.1002/lite.200800074

Johnson, M. B., and Wen, Z. (2009). Production of biodiesel from the microalga Schizochytrium limacinum by direct transesterification of algal biomass. Energy Fuels 23, 5179-5183. doi:10.1021/ef900704h

Jones, J., Manning, S., Montoya, M., Keller, K., and Poenie, M. (2012). Extraction of algal lipids and their analysis by HPLC and mass spectrometry. J. Am. Oil Chem. Soc. 89, 1371-1381. doi:10.1007/s00216-011-5376-6

Khan, S. A., Rashmi Hussain, M. Z., Prasad, S., and Banerjee, U. (2009). Prospects of biodiesel production from microalgae in India. Renew. Sustain. Energ. Rev. 13, 2361-2372. doi:10.1016/j.rser.2009.04.005

Khanal, S. K., Grewell, D., Sung, S., and Leeuwen, J. (2007). Ultrasound applications in wastewater sludge pretreatment: a review. Crit. Rev. Environ. Sci. Technol. 37, 277-313. doi:10.1080/10643380600860249

Kim, J., and Yoo, G. (2013). Methods of downstream processing for the production of biodiesel from microalgae. Biotechnol. Adv. 31, 862-876. doi:10.1016/j. biotechadv.2013.04.006

Kim, Y., and Choi, Y. (2012). Ionic liquid-mediated extraction of lipids from algal biomass. Bioresour. Technol. 109, 312-315. doi:10.1016/j.biortech.2011.04.064

Klein-Marcuschamer, D., and Simmons, B. (2011). Techno-economic analysis of a lignocellulosic ethanol biorefinery with ionic liquid pre-treatment. Biofuels Bioprod. Biorefin. 5, 562-569. doi:10.1002/bbb.303

Lee, A. K., Lewis, D. M., and Ashman, P. J. (2012). Disruption of microalgal cells for the extraction of lipids for biofuels: processes and specific energy requirements. Biomass Bioenergy 46, 89-101. doi:10.1016/j.biombioe.2012.06.034

Lee, J. Y., Yoo, C., Jun, S. Y., Ahn, C. Y., and Oh, H. M. (2010). Comparison of several methods for effective lipid extraction from microalgae. Bioresour. Technol. 101, S75-S77. doi:10.1016/j.biortech.2009.03.058

Lee, S. J., Yoon, B. D., and Oh, H. M. (1998). Rapid method for the determination of lipid from the green alga Botryococcus braunii. Biotechnol. Tech. 12, 553-556. doi:10.1023/A:1008811716448

Levine, R. B., Pinnarat, T., and Savage, P. E. (2010). Biodiesel production from wet algal biomass through in situ lipid hydrolysis and supercritical transesterification. Energy Fuels 24, 5235-5243. doi:10.1021/ef1008314

Li, Q., Jiang, X., He, Y., Li, L., Xian, M., and Yang, J. (2010). Evaluation of the biocompatible ionic liquid 1-methyl-3-methylimidazolium dimethylphosphite pretreatment of corn cob for improved saccharification. Appl. Microbiol. Biotechnol. 87, 117-126. doi:10.1007/s00253-010-2484-8

Liang, K., Zhang, Q., and Cong, W. (2012). Enzyme-assisted aqueous extraction of lipid from microalgae. J. Agric. Food Chem. 60, 11771-11776. doi:10.1021/ jf302836v

Marcato, B., and Vianello, M. (2000). Microwave-assisted extraction by fast sample preparation for the systematic analysis of additives in polyolefins by high performance liquid chromatography. J. Chromatogr. 869, 285-300. doi:10.1016/S00219673(99)00940-1

Markham, B. L., Ong, L., Barsi, J. A., Mendenhall, J. A., Lencioni, D. E., Helder, D. L., et al. (2006). "Radiometric calibration stability of the EO-1 advanced land imager: 5 years on-orbit," in Proceedings of SPIE Conference 6361 on Sensors, Systems, and Next-Generation Satellites X, SPIE, Vol. 6361, eds R. Meynart, S. P. Neeck, and H. Shimoda (San Diego, CA), 66770U:1-12.

Mason, T. J., Lorimer, J. P., Bates, D. M., and Zhao, Y. (1994). Dosimetry in sonochemistry: the use of aqueous terephthalate ion as a fluorescence monitor. Ultrason. Sonochem. 1, S91-S95. doi:10.1016/1350-4177(94)90004-3

Matyash, V., Liebisch, G., Kurzchalia, T. V., Shevchenko, A., and Schwudke, D. (2008). Lipid extraction by methyl-tert-butyl ether for high-throughput lipidomics. J. Lipid Res. 49, 1137-1146. doi:10.1194/jlr.D700041-JLR200

Ninomiya, K., Kamide, K., Takahashi, K., and Shimizu, N. (2012). Enhanced enzymatic saccharification of kenaf powder after ultrasonic pretreatment in ionic liquids at room temperature. Bioresour. Technol. 103, 259-265. doi:10.1016/j. biortech.2011.10.019

Pare, J. R. J., Matni, G., Bélanger, J. M. R., Li, K., Rule, C., and Thibert, B. (1997). Use of the microwave-assisted process in extraction of fat from meat, dairy, and egg products under atmospheric pressure conditions. J. AOAC Int. 80, 928-933.

Ramesh, D. (2013). "Lipid identification and extraction techniques," in Biotechnological Applications of Microalgae: Biodiesel and Value-added Products, ed. F. Bux (Boca Raton, FL: CRC Press), 89-97. 
Ranjan, A., Patil, C., and Moholkar, V. S. (2010). Mechanistic assessment of microalgal lipid extraction. Ind. Eng. Chem. Res. 49, 2979-2985. doi:10.1021/ ie9016557

Rawat, I., Ranjith Kumar, R., Mutanda, T., and Bux, F. (2013). Biodiesel from microalgae: a critical evaluation from laboratory to large scale production. Appl. Energy 103, 444-467. doi:10.1016/j.apenergy.2012.10.004

Refaat, A. A., El Sheltawy, S. T., and Sadek, K. U. (2008). Optimum reaction time, performance and exhaust emissions of biodiesel produced by microwave irradiation. Int. J. Environ. Sci. Technol. 5, 315-322. doi:10.1007/BF03326026

Richmond, A. (2004). Handbook of Microalgal Culture: Biotechnology and Applied Phycology. Oxford: Blackwell.

Roessler, P. G., Brown, L. M., Dunahay, T. G., Heacox, D. A., Jarvis, E. E., and Schneider, J. C. (1994). Genetic-engineering approaches for enhanced production of biodiesel fuel from microalgae. ACS Symp. Ser. 566, 255-270. doi:10.1021/bk-1994-0566.ch013

Rosenberg, U., and Bogl, W. (1987). Microwave thawing, drying, and baking in the food industry. Food Technol. 41, 85-91.

Ruan, C., Jun, T., and Hong, G. (2006). Kinetics of leaching flavonoids from Pueraria lobata with ethanol. Chin. J. Chem. Eng. 14, 402-406. doi:10.1016/S10049541(06)60091-8

Sawayama, S., Inoue, S., Dote, Y., and Yokoyama, S. Y. (1995). CO 2 fixation and oil production through microalga. Energ. Convers. Manag. 36, 729-731. doi:10.1016/0196-8904(95)00108-P

Sheehan, J., Dunahay, T., Benemann, J., and Roessler, P. (1998). A Look Back at the U.S. Department of Energy's Aquatic Species Program - Biodiesel from Algae. Report NREL/TP-580-24190. Golden, CO: National Renewable Energy Laboratory.

Sheng, J., Vannela, R., and Rittmann, B. E. (2011). Evaluation of methods to extract and quantify lipids from Synechocystis PCC 6803. Bioresour. Technol. 102, 1697-1703. doi:10.1016/j.biortech.2010.08.007

Sommerfeld, M., Chen, W., Hu, Q., Giorgi, D., Navapanich, T., Ingram, M., et al. (2008). Application of Electroporation for Lipid Extraction from Microalgae. Seattle, WA: Algae Biomass Summit.

Sostaric, M., Klinar, D., Bricelj, M., Golob, J., Berovic, M., and Likozar, B. (2012). Growth, lipid extraction and thermal degradation of the microalga Chlorella vulgaris. N. Biotechnol. 29, 325-331. doi:10.1016/j.nbt.2011.12.002
Suslick, K. S., and Flannigan, D. J. (2008). Inside a collapsing bubble: sonoluminescence and the conditions during cavitation. Annu. Rev. Phys. Chem. 59, 659-683. doi:10.1146/annurev.physchem.59.032607.093739

Taher, H., Al-Zuhair, S., Al-Marzouqi, A. H., Haik, Y., and Farid, M. (2014). Effective extraction of microalgae lipids from wet biomass for biodiesel production. Biomass Bioenergy 66, 159-167. doi:10.1016/j.biombioe.2014.02.034

Wang, X., Li, H., Cao, Y., and Tang, Q. (2011). Cellulose extraction from wood chip in an ionic liquid 1-allyl-3-methylimidazolium chloride (AmimCl). Bioresour. Technol. 102, 7959-7965. doi:10.1016/j.biortech.2011.05.064

Weerheim, A. M., Kolb, A. M., Sturk, A., and Nieuwland, R. (2002). Phospholipid composition of cell-derived microparticles determined by one-dimensional high-performance thin-layer chromatography. Anal. Biochem. 302, 191-198. doi:10.1006/abio.2001.5552

Yoo, G., Park, W. K., Kim, C. W., Choi, Y. E., and Yang, J. W. (2012). Direct lipid extraction from wet Chlamydomonas reinhardtii biomass using osmotic shock. Bioresour. Technol. 123, 717-722. doi:10.1016/j.biortech.2012.07.102

Conflict of Interest Statement: The authors declare that the research was conducted in the absence of any commercial or financial relationships that could be construed as a potential conflict of interest.

Received: 12 November 2014; accepted: 10 December 2014; published online: 08 January 2015.

Citation: Ranjith Kumar R, Hanumantha Rao P and Arumugam M (2015) Lipid extraction methods from microalgae: a comprehensive review. Front. Energy Res. 2:61. doi: 10.3389/fenrg.2014.00061

This article was submitted to Bioenergy and Biofuels, a section of the journal Frontiers in Energy Research.

Copyright (c) 2015 Ranjith Kumar, Hanumantha Rao and Arumugam. This is an openaccess article distributed under the terms of the Creative Commons Attribution License (CC BY). The use, distribution or reproduction in other forums is permitted, provided the original author(s) or licensor are credited and that the original publication in this journal is cited, in accordance with accepted academic practice. No use, distribution or reproduction is permitted which does not comply with these terms. 